\title{
Pengaruh Fortifikasi Kandungan Bahan Organik dari Pupuk Organik Berbahan Baku Feses Sapi Potong dan Feses Ayam Niaga Pedaging Terhadap Bahan Kering Rumput Gajah
}

\author{
PRAYOGI SUNU ${ }^{1}$, DEWI NUR ANGGRAENI ${ }^{2}$ \\ ${ }^{1}$ Fakultas Peternakan Universitas Boyolali \\ J1. Pandanaran No. 405, Winong, Kab.Boyolali, Jawa Tengah 57315 \\ email: prayogisunusptmsi@gmail.com \\ ${ }^{2}$ Jurusan Biologi, Fakultas Biologi, Universitas Medan Area \\ J1. Kolam No.1 Medan Estate 20223 \\ email: dewinur.anggraeni@gmail.com
}

\begin{abstract}
Fortification effects of beef cattle feces with broiler chicken feces on dry matter of elephant grass was carried in the Industrial Area of Superior manure Compost, village district of Mipiran, Padamara, Purbalingga, and Experimental Farm, Faculty of Animal Science of Jenderal Soedirman University and Soil Science Laboratory of the Faculty of Agriculture, Sebelas Maret University Surakarta. This study was aim to determine the effect of commercial broiler chicken feces as the substitute for feces of beef cattle from the aspect of organic matter content and to determine the effect of fertilizer dry matter productions of elephant grass.

The materials used were the feces of beef cattle as much as $930 \mathrm{~kg}$, the commercial broiler chicken feces, $270 \mathrm{~kg}$ and $2.4 \mathrm{lt}$ EM4. This research method used Completely Randomized Design (CRD) with four treatments (R), namely: R0: 100\% beef cattle feces (50 kg), R1: $85 \%$ of beef cattle feces $(42,5 \mathrm{~kg})$ of commercial broiler chicken feces $+15 \%(7,5 \mathrm{~kg}), \mathrm{R} 2: 70 \%$ of beef cattle feces $(35 \mathrm{~kg})$ of commercial broiler chicken feces $+30 \%(15 \mathrm{~kg}), \mathrm{R} 3: 55 \%$ of beef cattle feces $(27,5 \mathrm{~kg})$ of commercial broiler chicken feces $+45(22,5 \mathrm{~kg})$ with six replications.

The results showed that the averages of organic matter content of R0, R1, R2, and R3 were $43,071 \%, 34,075 \%, 27,815 \%$, and $36,098 \%$ respectively. The result of analysis of variance showed that the averages of organic matter that did not use commercial broiler chicken feces (R0) was higher than using commercial broiler chicken feces.

The results of analysis showed that administration of compost on the grass did not affect significantly $(\mathrm{P}>0,05)$ on fresh production of elephant grass, presumably because it had not decomposed completely. Compost nutrient content was low, therefore, was not sufficient to provide additional nutrients needed by the plants.
\end{abstract}

Keywords: beef cattle, broiler chicken, dry matter, elephant grass, fortification

\section{INTISARI}

Pengaruh fortifikasi kandungan organik dari pupuk organik berbahan baku feses sapi potong dan ayam niaga pedaging terhadap bahan kering rumput gajah telah dilaksanakan di Kawasan Industri Kompos Kandang Unggul, desa Mipiran Kecamatan Padamara Kabupaten Purbalingga, dan Experimental Farm Fakultas Peternakan Universitas Jenderal Soedirman dan Laboratorium Ilmu Tanah Fakultas Pertanian Universitas Negeri Sebelas Maret Surakarta. Tujuan penelitian ini adalah untuk mengetahui pengaruh feses ayam niaga pedaging sebagai pencampur feses sapi potong untuk bahan baku pembuatan pupuk organik dari aspek kandungan bahan organik dan mengetahui pengaruh pemberian pupuk hasil fortifikasi terhadap bahan kering rumput gajah.

Materi yang digunakan adalah feses sapi potong sebanyak $930 \mathrm{~kg}$, feses ayam niaga pedaging $270 \mathrm{~kg}$, EM4 2,4 liter. Metode penelitian ini menggunakan Rancangan Acak Lengkap (RAL) dengan empat perlakuan (R) yaitu: R0: feses sapi potong 100\% (50 kg), R1: feses sapi potong 85\% 
$(42,5 \mathrm{~kg})+$ feses ayam niaga pedaging $15 \%(7,5 \mathrm{~kg}), \mathrm{R} 2$ : feses sapi potong $70 \%(35 \mathrm{~kg})+$ feses ayam niaga pedaging 30\% (15 kg), R3: feses sapi potong $55 \%(27,5 \mathrm{~kg})+$ feses ayam niaga pedaging $45(22,5 \mathrm{~kg})$ dengan enam kali ulangan.

Hasil penelitian menunjukkan bahwa rata-rata kandungan bahan organik dari R0, R1, R2, dan R3, masing-masing 43,071\%, 34,075\%, 27,815\%, dan 36,098\%. Analisis hasil variansi menunjukkan bahwa rata-rata bahan organik yang tidak menggunakan kotoran ayam broiler komersial (R0) lebih tinggi daripada menggunakan setiap perlakuan kompos.

Hasil analisis seragam menunjukkan pemberian pupuk kompos pada rumput gajah berpengaruh tidak nyata $(\mathrm{P}>0,05)$ terhadap produksi hijauan segar rumput gajah, hal tersebut diduga karena kompos belum terdekomposisi dengan sempurna dan kandungan unsur hara kompos rendah sehingga belum cukup memberikan unsur hara tambahan yang dibutuhkan oleh tanaman.

Kata kunci: ayam niaga pedaging, bahan kering, fortifikasi, rumput gajah, sapi potong

\section{PENDAHULUAN}

Rumput gajah (Pennisetum purpureum) varietas Thailand merupakan salah satu hijauan pakan untuk ternak ruminansia. Rumput gajah varietas Thailand bertekstur kasar sehingga cocok untuk ternak ruminansia besar. Rumput tersebut merupakan rumput yang baru diintroduksi dari Thailand sehingga potensinya belum banyak diketahui. Rumput gajah varietas Thailand mempunyai beberapa keunggulan dibandingkan rumput raja yaitu: permukaan daun bagian atas tidak berbulu, sehingga diduga lebih disukai ternak, di samping itu rumput gajah varietas Thailand lebih tahan kering jika dibandingkan rumput raja, Potensi genetik rumput gajah yang unggul harus ditunjang dengan tatalaksana pemeliharaan yang baik. Salah satu bagian dari tatalaksana pemeliharaan tanaman rumput gajah adalah pemupukan. Prospek rumput gajah cukup baik bila dilakukan pemupukan yang baik pula. Dengan memanen pada saat pertumbuhan vegetatif atau dengan menggunakan kultivar yang baik akan mencapai nilai pakan yang tinggi. Keuntungan dari rumput gajah varietas Hawai adalah kemampuannya berproduksi, dapat ditanam dalam jumlah besar, dan dapat diusahakan secara mekanis atau juga untuk pertanian atau peternakan skala kecil (Sinaga, 2007).

Pupuk adalah bahan yang diberikan ke dalam tanah baik yang organik maupun anorganik dengan maksud untuk mengganti kehilangan unsur hara dari dalam tanah dan bertujuan untuk meningkatkan produksi tanaman yang optimal. Produksi tanaman yang optimal adalah menghasilkan produksi hijauan segar maupun bahan kering yang tinggi, sehingga akan meningkatkan produksi ternak karena kebutuhan pakan ternak tercukupi. Bagi peternak, produksi optimal yang diperoleh dengan modal yang rendah akan menguntungkan sehingga pendapatan meningkat dan kesejahteraan peternak dapat tercapai (Paly, 2013; Wahyudi dan Herdraningsih, 2005; Wibowo dan Cristiani, 2002).

Berbagai penelitian telah dilakukan untuk meningkatkan kualitas kompos kandang dengan pemanfaatan limbah organik. Salah satu upaya peningkatan kualitas kompos kandang yang belum pernah dilakukan adalah dengan model fortifikasi, yaitu peningkatan kualitas kompos kandang dengan menggunakan bahan organik lain sebagai bahan baku pembuatan kompos sehingga diperoleh kompos kandang dengan kualitas yang lebih baik.

\section{METODE}

Pembuatan Kompos. Penimbangan feses sapi potong dan feses ayam niaga petelur disesuaikan dengan dosis per perlakuan sebagai berikut:

R0: Feses sapi potong 100\% (50 kg), Feses ayam niaga petelur $0 \%(0 \mathrm{~kg})$

R1: Feses sapi potong $85 \%(42,5 \mathrm{~kg})$, Feses ayam niaga petelur $15 \%(7,5 \mathrm{~kg})$

R2: Feses sapi potong 70\% (35 kg), Feses ayam niaga petelur $30 \%(15 \mathrm{~kg})$ 
R3: Feses sapi potong 55\% (27,5 kg), Feses ayam niaga petelur $45 \%(22,5 \mathrm{~kg})$

Setelah selesai ditimbang campur feses sapi potong dengan feses ayam petelur kemudian diaduk hingga merata. Menuangkan campuran larutan EM4 2,4 liter + gula pasir $0,75 \mathrm{~kg}+$ air yang ke dalam campuran feses dan diaduk hingga merata. Campuran tersebut kemudian dibentuk gundukan dan ditutup dengan karung. Jangka waktu 7 hari gundukan tersebut dilakukan pembalikan, setelah 14 hari kompos sudah jadi dan siap untuk digunakan (Lingga, 2000).

Persiapan Lahan. Lahan yang akan digunakan sejumlah 24 petak. Stek ditanam pada petak yang sudah disediakan sejumlah 15 stek. Pemberian/pengacakan label pada setiap petak untuk menentukan perlakuan yang diberikan. Pemupukan dilakukan pada saat rumput sudah berumur 20 hari dari penanaman atau rumput sudah berakar dan memiliki tunas. Rumput gajah diberi pupuk kompos sebanyak $0,5 \mathrm{~kg}$ setiap stek sehingga banyaknya pupuk yang diberikan adalah 7,5 $\mathrm{kg} /$ petak dengan cara memendam pupuk di dalam tanah sedalam $10 \mathrm{~cm}$ dan jarak dari tanaman sekitar $15 \mathrm{~cm}$. Cara pemberian pupuk sebagai berikut:

Perlakuan 0: Kompos (R0) diberikan pada satu stek rumput gajah

Perlakuan 1: Kompos (R1) diberikan pada satu stek rumput gajah

Perlakuan 2: Kompos (R2) diberikan pada satu stek rumput gajah

Perlakuan 3: Kompos (R3) diberikan pada satu stek rumput gajah

\section{Pengukuran Kandungan Bahan}

Organik Kompos. Kadar bahan organik menggunakan metode pembakaran dengan tanur (Aristiani, 2010) sebagai berikut: (1) Mengeringkan cawan dalam oven dengan suhu $105^{\circ} \mathrm{C}$ selama 1 jam kemudian dimasukan kedalam desikator kurang lebih 15 menit; (2) menimbang cawan (A gram ); (3) Memasukan sampel kompos kedalam cawan kemudian dikeringkan dalam oven pada suhu $105^{\circ} \mathrm{C}$ selama 14 jam; (4) Masukkan cawan yang berisi sampel kedalam desikator selama
15 menit; (5) Menimbang kembali (B gram) setelah ditanur pada suhu $600^{\circ} \mathrm{C}$ selama 3 jam; (6) Masukkan kedalam desikator kurang lebih 15 menit setelah abu diperoleh dari hasil pembakaran dengan tanur dan setelah dingin ditimbang kembali (C gram); (7) Menghitung kadar abu; (8) Menetapkan kadar bahan organik melalui perhitungan yaitu $100 \%$-\% abu.

Produksi Bahan Kering (Bobot BK). Perhitungan produksi bahan kering sesuai petunjuk Muhamad (2010) yaitu dengan cara: (1) Cawan dikeringkan terlebih dahulu selama 1 jam dalam oven pada suhu $105^{\circ} \mathrm{C}$, lalu didinginkan dalam eksikator kemudian beratnya ditimbang (x); (2) Sampel ditimbang seberat (y), dimasukkan ke dalam cawan, kemudian dimasukkan ke dalam oven selama 4-6 jam pada suhu $105^{\circ} \mathrm{C}$, lalu didinginkan dalam deksikator dan ditimbang kembali; (3) Pekerjaan ini diulang sampai 3 kali, hingga dicapai berat konstan (z); (4) Adapun rumus penentuan kadar bahan kering sebagai berikut:

$$
\text { Kadar } B K=\frac{(z-x)}{y} \times 100 \%
$$

Rancangan Percobaan. Penelitian menggunakan Rancangan Acak Lengkap (RAL), dengan perlakuan sebagai berikut:

R0: Feses sapi potong 100\% (50 kg), Feses ayam niaga pedaging $0 \%(0 \mathrm{~kg})$

R1: Feses sapi potong 85\% (42,5 kg), Feses ayam niaga pedaging $15 \%(7,5 \mathrm{~kg})$

R2: Feses sapi potong 70\% (35 kg), Feses ayam niaga pedaging $30 \%(15 \mathrm{~kg})$

R3: Feses sapi potong 55\% (27,5 kg), Feses ayam niaga pedaging $45 \%(22,5 \mathrm{~kg})$

Model matematik yang digunakan adalah: Yijk $=\mu+\tau i+\varepsilon i j$

Keterangan:

Yijk : Variabel respon yang diamati dan pengaruh taraf $\mathrm{ke}-\mathrm{i}$ ulangan $\mathrm{ke} \mathrm{j}$

$\mu \quad$ : Pengaruh rata - rata sebenarnya (nilai tengah respon)

$\tau$ i : Pengaruh sebenarnya dari taraf $\mathrm{ke}-\mathrm{i}$ perlakuan

eij : Galat percobaan 


\section{HASIL}

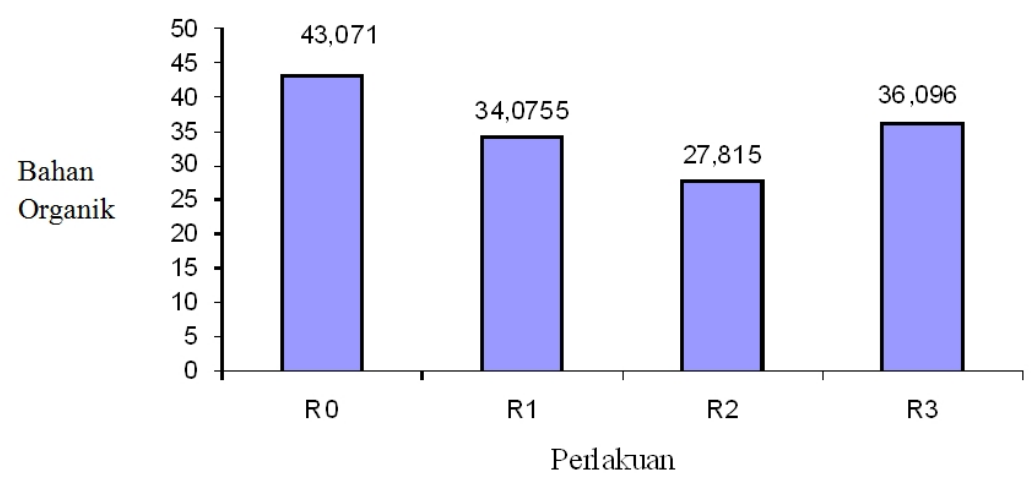

Gambar 1. diagram batang kandungan bahan organik

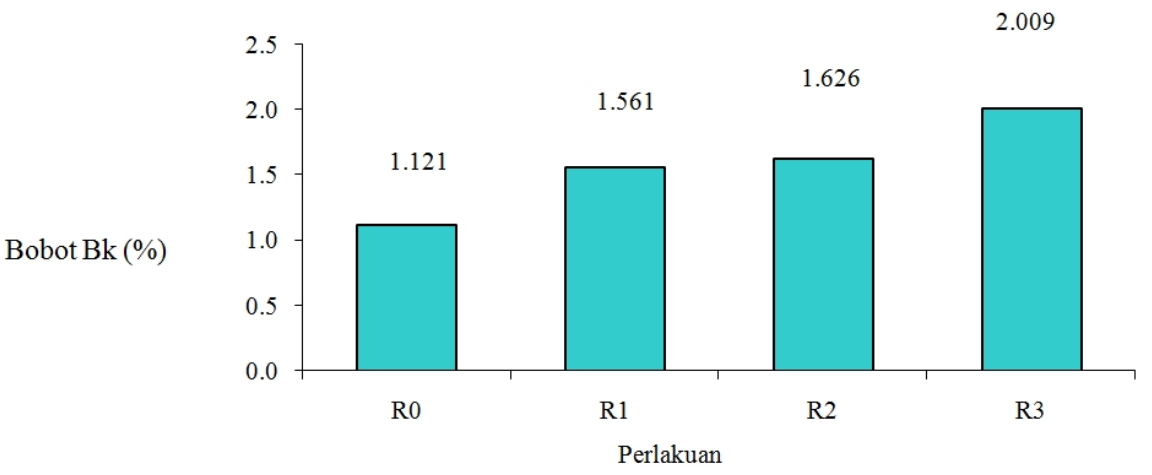

Gambar 2. diagram batang bahan kering rumput gajah

\section{PEMBAHASAN}

Lokasi Penanaman Rumput Gajah

(Pennisetum purpureum). Lokasi penanaman rumput gajah adalah di lahan kebun rumput Experimental Farm Universitas Jenderal Soedirman Purwokerto dengan ketinggian kurang lebih $100 \mathrm{~m}$ di atas permukaan laut. Menurut Direktorat Jenderal Peternakan pada ketinggian 0 - 1500 meter di atas permukaan air laut rumput gajah dapat tumbuh dengan subur. Pada ketinggian kurang lebih 100 meter di atas permukaan laut seperti pada lokasi penanaman dinyatakan sesuai untuk pertumbuhan rumput gajah. Persyaratan $\mathrm{pH}$ yang dikehendaki oleh tanaman sangat bervariasi, kebanyakan tanaman tumbuh kurang baik pada $\mathrm{pH}$ kurang dari 5. Tanah yang memiliki $\mathrm{pH}$ antara 5,5 sampai 7,5 (mendekati netral) mengandung unsur hara dalam jumlah cukup banyak di dalam tanah. $\mathrm{pH}$ tanah mempengaruhi ketersediaan unsur hara. Ketersediaan unsur hara akan semakin tinggi jika $\mathrm{pH}$ tanah meningkat hingga berkisar antara 5,5 - 7,5 (mendekati netral). Umumnya unsur hara mudah diserap akar tanaman pada $\mathrm{pH}$ sekitar netral, karena pada $\mathrm{pH}$ tersebut unsur hara mudah larut dalam air, aktivitas biologi mikroorganisme juga optimal pada $\mathrm{pH}$ tanah tersebut. Bakteri berkembang dengan baik pada $\mathrm{pH}$ 5,5 atau lebih, sedangkan pada $\mathrm{pH}$ kurang dari 5,5 perkembangannya akan terhambat.

Hasil pengukuran derajat keasaman tanah (pH) di lahan penelitian menunjukkan $\mathrm{pH}$ tanah rata-rata 6,4. Berdasarkan hasil pengukuran $\mathrm{pH}$ tersebut maka keadaan tanah di lahan penelitian termasuk baik, diduga mikroorganisme dalam tanah juga dapat beraktivitas dengan baik sehingga dapat meningkatkan kesuburan tanah.

Kandungan Bahan Organik Kompos. Fungsi biologis bahan organik adalah sebagai sumber energi dan makanan tanah, sehingga dapat meningkatkan aktivitas mikroorganisme tanah yang bermanfaat dalam penyediaan hara tanaman. Kandungan bahan organik 
merupakan salah satu parameter kualitas kompos, semakin tinggi kandungan bahan organiknya berarti kompos tersebut semakin berkualitas. Rataan Bahan organik pada kompos seluruh perlakuan memiliki rataan $35,26 \%$. Bahan organik pada perlakuan $\mathrm{R}_{0}$ memperoleh rataan $43,07 \%$, perlakuan $R_{1}$ sebesar $34,07 \%, \quad R_{2}$ sebesar 27,81\%, $R_{3}$ mempunyai bahan organik dengan rataan sebesar 36,09\% (Gambar 1).

Berdasarkan (Gambar 1) rataan bahan organik pada kompos yang tidak menggunakan feses ayam niaga pedaging $\left(\mathrm{R}_{0}\right)$ lebih tinggi dibandingkan dengan kompos menggunakan feses pada tiap perlakuan, namun demikian ternyata pada pengujian lebih lanjut dengan BNT menunjukan bahwa penggunaan feses ayam niaga pedaging sebagai fortifikator tidak berpengaruh nyata pada bahan organik kompos. Menurut Astuti (2005), salah satu standar kualitas kompos yaitu mengandung bahan organik minimum $27 \%$ dan maksimum 58\%. Selain itu Sutanto (2002) menyatakan bahwa hasil akhir kompos mengandung $30 \%-60 \%$ bahan organik. Berdasarkan hasil penelitian tersebut dapat diasumsikan bahwa dari semua perlakuan dalam penelitian masih memenuhi standar kualitas kompos yang baik karena hasil rataannya diatas $30 \%$. Hal ini berarti kompos yang dihasilkan dalam penelitian ini masih memenuhi standar dari Sutanto (2002) maupun Astuti (2005).

Hasil penelitian kandungan bahan organik menunjukan adanya penurunan. Kandungan bahan organik paling rendah dicapai oleh $\mathrm{R}_{2}$ dimana komposisi bahan untuk feses sapi sebanyak 70\% (35 kg), dan feses ayam niaga pedaging 30\% ( $15 \mathrm{~kg}$ ), penurunan dilanjutkan oleh perlakuan $\mathrm{R}_{1}$ yaitu sebesar $34,075 \%$, kemudian $\mathrm{R}_{3}$ yaitu 36,098 hal ini diduga antara lain dikarenakan adanya senyawa karbon yang hilang ke udara selama proses pengomposan. Persenyawaan zat arang (C), selulosa, hemiselulosa, dan lain-lain diurai menjadi $\mathrm{CO}_{2}$ dan air akan hilang ke udara dan menyebabkan kadar karbon akan menurun (Triatmojo, 2001). Rataan bahan bahan organik tertinggi dicapai oleh perlakuan $\mathrm{R}_{0}$ atau kontrol dimana bahan baku hanya feses sapi potog saja yaitu sebesar 43,071. Hal ini diduga disebabkan adanya proses dekomposisi yang berlangsung secara alami sehingga panas dan penguapan yang dihasilkan juga rendah sehingga diperoleh rataan yang lebih tinggi. Untuk lebih jelasnya dapat dilihat pada gambar 2 .

Bahan organik memiliki peranan penting dalam usaha peningkatan efisiensi penggunaan pupuk, karena dapat memasok berbagai unsur hara makro dan mikro dan hampir seluruh kandungan hara dalam bahan organik dapat diserap tanaman setelah melalui proses dekomposisi. Bahan organik juga merupakan sumber energi bagi mikroorganisme dan setelah mikroorganisme tersebut mati akan melepas unsur hara sehingga dapat dimanfaatkan oleh tanaman (Purnomo, 2006).

Pengaruh Pupuk Organik Terhadap Produksi Bahan Kering Rumput Gajah. Hasil analisis seragam menunjukkan bahwa pemberian kompos berpengaruh tidak nyata terhadap produksi bahan kering hijauan rumput gajah $(\mathrm{P}>0,05)$. Produksi bahan kering dipengaruhi oleh produksi segar dan kadar bahan kering hijauan. Rumput gajah yang diberi pupuk kompos produksi hijauan segarnya rendah sehingga menghasilkan produksi bahan kering yang rendah. Produksi hijauan segar yang rendah diduga karena rumput kekurangan nitrogen, kandungan nitrogen dalam kompos rendah sehingga pertumbuhan tanaman tidak optimal sehingga menghambat pertumbuhannya dan menyebabkan produksi rendah. Apabila unsur nitrogen yang tersedia lebih banyak dari unsur lainnya, daun dapat tumbuh lebih lebar, maka proses fotosintesis lebih banyak terjadi, jika proses fotosintesis lebih banyak maka nutrisi bagi tanaman juga lebih banyak sehingga dapat meningkatkan pertumbuhan dan produksi tanaman. Pada rumput gajah yang diberi pupuk kompos produksi hijauan segarnya rendah sedangkan kadar bahan kering hijauannya relatif sama sehingga menghasilkan produksi bahan kering yang rendah pula.

Hasil Penelitian (Gambar 2) dapat di lihat bahwa perlakuan $R_{3}$ menunjukkan rataan 
bobot Bahan Kering (BK) rumput gajah lebih besar yaitu 2,009\% dibandingkan dengan kontrol $\left(\mathrm{R}_{0}\right)$ sebesar $1,121 \%$. Hal ini disebabkan oleh peningkatan penggunaan pupuk kompos untuk memenuhi kebutuhan rumput gajah akan unsur hara yang diperlukan untuk meningkatkan kadar bahan kering.

\section{KESIMPULAN}

1. Berdasarkan penelitian tersebut dapat diasumsikan bahwa dari semua perlakuan dalam penelitian masih memenuhi standar kualitas kompos yang baik karena hasil rataan bahan organik diatas $30 \%$. Bahan organik pada perlakuan $\mathrm{R}_{0}$ memperoleh rataan $43,07 \%$, perlakuan $R_{1}$ sebesar $34,07 \%, \mathrm{R}_{2}$ sebesar $27,81 \%, \mathrm{R}_{3}$ mempunyai bahan organik dengan rataan sebesar 36,09\%.

2. Hasil analisis menunjukkan pemberian pupuk kompos pada rumput gajah berpengaruh tidak nyata $(\mathrm{P}>0,05)$ terhadap produksi hijauan segar rumput gajah.

3. Pada rumput gajah yang diberi pupuk kompos produksi hijauan segarnya rendah sedangkan kadar bahan kering hijauan relatif sama dengan produksi segarnya sehingga menghasilkan produksi bahan kering yang rendah pula.

\section{DAFTAR PUSTAKA}

Aristiani D. 2010. Fortifikasi Feses Sapi Potong Sebagai Bahan Baku Kompos Dengan Humus Hutan Pinus Ditinjau Dari Kandungan Bahan Organik dan Sulfur. [Skripsi]. Purwokerto: Fakultas
Peternakan Universitas Jenderal Soedirman.

Astuti A. 2005. Aktivitas Proses Dekomposisi Berbagai Bahan Organik Dengan Aktivator Alami dan Buatan. [Skripsi]. Yogyakarta: Jurusan Budidaya Pertanian. Universitas Muhammadiyah Yogyakarta.

Basir P. 2013. Pola Hubungan Antara Jumlah Kelahiran Dengan Jumlah Betina dan Pejantan Produktif Pada Ternak Sapi. Biogenesis 1 (2): 101-109. https://dx.doi.org/10.24252/bio.v1i2.455

Lingga P. 2000. Petunjuk Penggunaan Pupuk. Jakarta: Penebar Swadaya. hal 1-10

Purnomo E. 2006. Peranan Bahan Organik Untuk Menyuburkan Tanah. Balai pengkajian Teknologi Pertanian. Info Teknologi Pertanian 77 (1): 2

Sinaga R. 2007. Analisis Model Ketahanan Rumput Gajah dan Rumput Raja Akibat Cekaman Kekeringan Berdasarkan Respon Anatomi Akar dan Daun. Jurnal Biologi Sumatera 2 (1): 17-20

Sutanto R. 2002. Penerapan Pertanian Organik. Yogyakarta: Kanisius. hal 47-50

Wahyudi A. dan Herdraningsih L. 2005. Evaluasi Ketersedian Nitrogen, Phosphor dan Kalium Pada Manure Sapi Perah dengan Introduksi Bakteri Selulotik. [Proseding Seminar Nasional]. Prospek Pengembangan Peternakan Tanpa Limbah. Surakarta: Universitas Sebelas Maret 5 September 2005. hal 52

Wibowo DN dan Cristiani. 2002. Pengomposan Sampah Dapur Rumah Tangga Dengan Menggunakan Pemacu yang Berbeda dan Vermiculture. Journal of Rural Development 2 (1): 35-39. 